\title{
Chinese Language Learning Strategies
}

\section{Characteristic of Language Learners}

\author{
Anett Kozjek-Gulyás \\ Pázmány Péter Catholic University, Hungary
}

\begin{abstract}
The present paper analyzes the strategic choices for learning Chinese by 300 Hungarian university students. The survey summarizes the most often used Chinese language learning strategies and verbal language learning strategies of Hungarian language learners one by one. With the help of the method of multidimensional scaling, the survey got to the result that the preference of the general language learning strategies is characterized by a strong opposition. In the case of the choice and use of three strategies - the social, the meta-cognitive and the cognitive strategies, language learners prefer a combined choice or non-choice. While in the use of the emotional, compensation and memorization strategies, a strong opposition emerges. Those using memorization strategies less prefer the emotional and the compensation strategies. This is true vice versa as well, those using emotional strategies, use memorization and compensation strategies less often. While the relation of the general language learning strategies was characterized by a certain opposition, in the use of the verbal strategies a strict continuity could be detected. Hungarian language learners consider the use of almost all verbal strategies with few exceptions to be successful in their communication. The results of the Variables path analysis with Partial Least-Squares Estimation (LVPLS) model revealed all those connections that structurally exist among the three exogen background latent variables (language level, language learner style and the ascriptive background) and the two endogen latent variables (the language learning strategies and the verbal strategies). All of these latent variables measured with several manifest variables of the second exogen background variables, the language learning style showed the biggest affect to strategy use, this variable influences the successfulness of the learning of Chinese most strongly.
\end{abstract}

Keywords: Chinese language, language learning strategies, language learning styles, verbal language learning

The research of the language learning strategies going back to 40 years has a great theoretical and practical tradition (O'Malley \& Chamot, 1990; Oxford, 1990). Chinese researchers have been focusing on examining the strategies playing a role in the learning of the Chinese language since 2000 (Jiang, 2000; Wu, 2007; Xu, 2006). In recent years the growing demand for learning the Chinese language in all stages of education - with students of elementary, secondary and higher education, as well as inside and outside Europe has given a new direction and new frameworks to strategy research, and has also laid the foundation for the theoretical and practical background of teaching Chinese language.

Anett Kozjek-Gulyás, junior assistant professor, Faculty of Humanities and Social Sciences, Pázmány Péter Catholic University, Hungary. 
The purpose of the survey was to explore the language learning strategies and styles characteristic of the learning of the Chinese language. Another important aim of the survey was to reveal the correlations between the factors influencing the choice for the individual language learning strategies.

The correlations of the results of the survey may help us realize which language learning strategies and language learning styles play a definite role in the successful acquisition of Chinese, and also, how certain background variables influence the successful acquisition of the language.

The results of the research may be useful and included in the successful teaching of Chinese as a foreign language.

\section{Theoretical Background}

Several factors influence the kinds of language learning strategies we prefer, we use and we neglect during our language learning to various extents. Such a factor is the ascriptive background of the language learner (age and sex). The results of researches examining the connection between age and language learning pointed out the fact that each age group has its own age specific advantages and disadvantages (Ehrmann \& Oxford, 1989; Oyama, 1976; Lenneberg, 1967). It ensues from the age characteristics that the strategy use of children differs from the strategy use of adults. A deficiency of researches examining the language learning strategies of the Chinese language is that they do not examine the use of the language learning strategies of juvenile language learners.

As for gender, most researches focused on the differences between the strategy uses of the sexes. Women use the strategies more often and more flexibly, while men use them less and not that regularly (Oxford, Lavine, Felkins, Hollaway \& Saleh, 1996). Another research also stated that women prefer communication strategies more than men do, and during communication they use considerably more strategies than their male partners (Nyikos, 1987). The preference of this strategy is supported by the fact that women achieve better results in verbal language tests (Bárdos, 2000). Girls showed higher performance in writing skill tests as opposed to boys (Csapó, 2001). Women differ from men in the use of their emotional strategies as well in that they use a lot more emotional strategies when assessing their own deficiencies in knowledge than men (Young \& Oxford, 1997).

Oxford and Nyikos (1989) in their research arrived at the conclusion that women use significantly more often learning strategies such as form centric practice or strategies directly connected to the social factor of information gathering. Women use these strategies more and more often because they possess a strong social orientation, their language learning is less motivated by competition spirit and much more by cooperation, in this way they are able to adapt to the social norms a lot more easily than men. Women are much more sensitive and a lot more motivated to get better grades, they long for a kind of social acceptance a great deal more, they want to meet the expectations of society more, and they expect social acknowledgment from achieving better results (Oxford, Nyikos \& Ehrmann, 1988). Women are aim oriented, tend to study alone, summarize the texts read and also interpret certain words more (Nyikos, 1990).

The differences in strategy use between language learners show most in language learner styles. Language learners prefer different strategies according to the style they use during their language learning. Extroverts use a lot more social strategies than introverts. Sensitive types use more memorization strategies, while intuitive types use more compensation strategies. Thinkers use more metacognitive strategies, the perceptive ones apply more 
social strategies, open listeners like emotional strategies more, while reserved ones reject them (Ehrman \& Oxford, 1990).

The assumption is that the background of the language learners has an influence on both strategy groups, both on the language learner style of the language learner and also on their language level(as shown in Figer 1). In the survey the author would like to explore which factor influences which factor and to what extent in the structural correlation system between the two strategy groups, the style of the language learner and their language level.

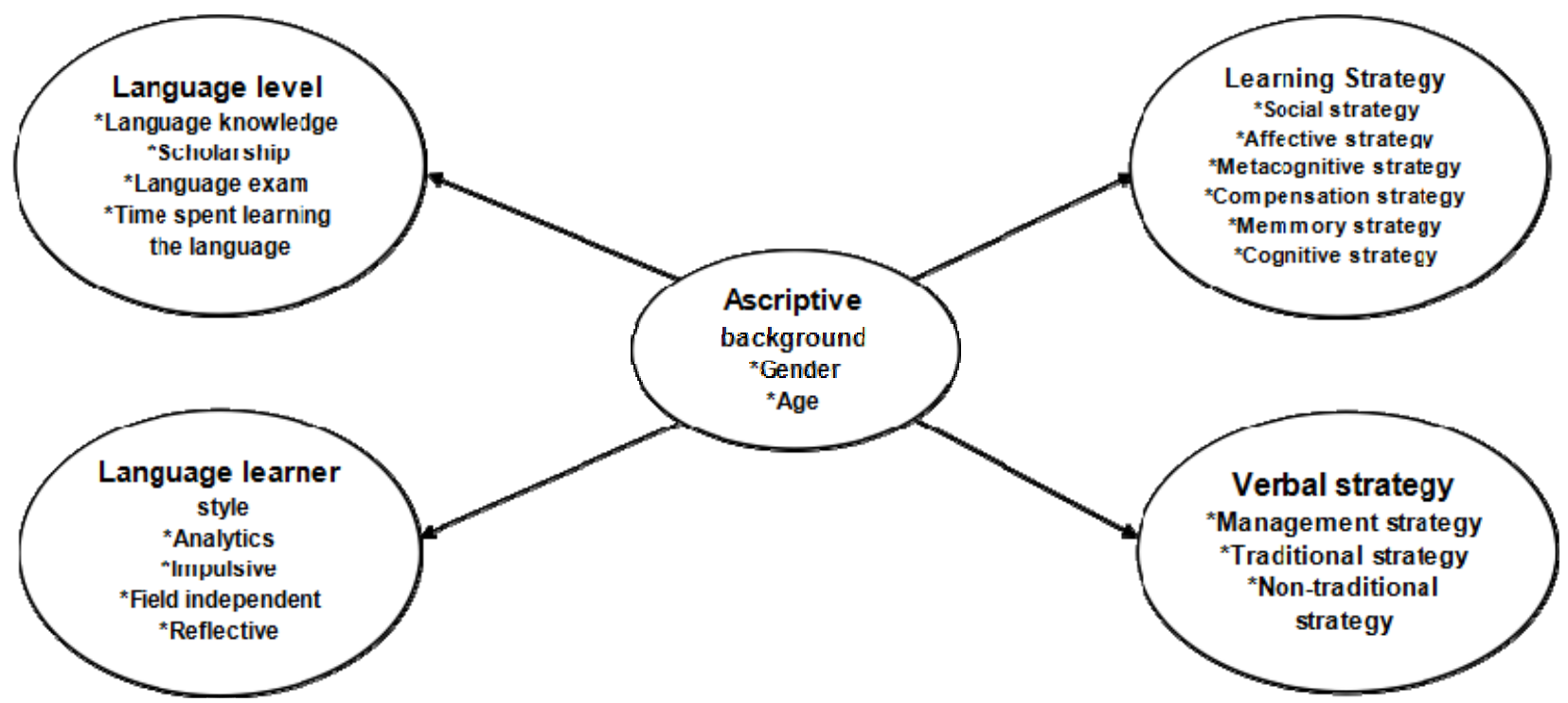

Figure 1. The influence of the language learner background on the use of the Chinese language learning strategies.

\section{Presentation of the Research Sample}

This research was a pilot study ${ }^{1}$, which served the purpose of exploring the correlations and correlation systems between the examined variables based on the measured data, that is why the selected sample is not representative, it does not give us the possibility to make general statements relevant for every Chinese language learner, however, it can be the starting point of a research that can make general conclusions based on the received results.

The author surveyed the language learning strategies and verbal language learning strategies of the Chinese language with the help of two questionnaires related to foreign language learning. One of them is the SILL (Strategy Inventory for Language Learning) developed by Oxford, and the other is the Learning Style Survey developed for the examination of language learning styles. I supplemented the questions with a section related to the personal data and language learning background of the people asked (sex, age, level of language knowledge, time spent learning the language, motivation for learning Chinese, possession of language exam, Chinese

\footnotetext{
1 The research was conducted from the Spring of 2011 to February 2013, with the participation of 227 university students in Budapest, Hungary. 148 women and 79 men participated in the sample. I differentiated six variables altogether in the research: gender, age: under 20: $15 \%$, between 20 and 30: $65 \%$, above 30: $20 \%$, according to the level of language knowledge: very good: $64 \%$, not good: $11 \%$, average: $25 \%$, according to the time spent learning Chinese: for two years: $28 \%$, under one year: $48 \%$, three years: $11 \%$, over four years: $13 \%$, language exam: yes: $29 \%$, no: $71 \%$, Chinese scholarship: has been to China: $16 \%$, has not been to China: $84 \%$.
} 
scholarship).

Data entry was performed with the spreadsheet handler program of Excel, the analysis of the data of the questionnaires was done with the use of the International Business Machines Corporation Statistical Product and Service Solutions (IBM SPSS) Statistics 20 mathematical statistical program package. During the analysis of the data I used variance analysis (Anova), discriminant analysis, Multidimensional Scaling, factor analysis and the LVPLS model—Latent Variables Path Analysis with Partial Least-Squares Estimation.

\section{Summary of the Results of the Survey}

The university student Chinese language learners followed the preference sequence below in the use of the language learning strategies (Table 1):

Table 1

Sequence of strategies used in learning Chinese

\begin{tabular}{llll}
\hline & Strategies & Mean & Std. deviation \\
\hline 1 & Compensation strategy & 4.09 & 0.52 \\
2 & Metacognitive strategy & 3.81 & 0.62 \\
3 & Social strategy & 3.57 & 0.70 \\
4 & Cognitive strategy & 3.51 & 0.58 \\
5 & Memory strategy & 3.12 & 0.71 \\
6 & Affective strategy & 3.11 & 0.68 \\
\hline
\end{tabular}

Besides compensation strategy, the metacognitive, the social and the cognitive strategies got listed among the often used strategies of university student language learners ${ }^{2}$ (Oxford, 1990, p. 300). However, the frequency value of the cognitive strategy fell behind the frequency values of the metacognitive and social strategies, which means that university student language learners use compensation, metacognitive and social strategies more often than cognitive strategies during their Chinese language learning. The low usage frequency of the memorization and emotional strategy means that university student language learners use these two strategies only rarely in order to make their language learning more successful.

Language learners are intensive strategy users, they apply a lot of strategies during their Chinese language learning. The compensation strategy is a language learning strategy applied by the language learner in order to overcome difficulties coming from deficiencies in knowledge (Oxford, 1990, p. 300). The use of the compensation strategy, which is directed toward covering up and overcoming language learning deficiencies is frequent rather among less good language learners ( Napravszky, Judiy \& Katalin, 2009, p. 71). With language learners the use of the compensation strategy showed the highest usage value (average $=4.09$ ). Of the questions measuring the use of the compensation strategies, the use of the strategy that reads "in learning Chinese the knowledge of Chinese culture is important" causes deficiencies in language learning (average $=4.3$ ).

Besides the use of the compensation strategies, the high usage frequency of the metacognitive strategy group (average $=3.81$ ) is characteristic of the language learners. Out of these the one that reads "I always listen to what

\footnotetext{
${ }^{2}$ According to Oxford, as long as the mean of the occurrence frequency of a certain strategy falls between $1,0-1,4$, it is a not used strategy. A value falling between 1, 5-2, 4 refers to a little used strategy, a value between 2, 5-3, 4 is a rarely used, while a value between 3,5-4, 4 refers to a often used strategy, finally a value between 4, 5-5, 0 is a quite of ten used or always used strategy.
} 
the teacher is saying at the lesson" (average $=4.4$ ) - directed at focusing attention, and the one labeled "I am trying to find the way of how I could become a better language learner" (average $=4.22$ ) -measuring the outer control strongly regulating personal learning - top the list (Oxford, 1990, p. 137).

The research results of the language learning strategies of the Chinese language have shown considerable differences in the use of the metacognitive strategies of the language learners of individual nations. Chinese language learners of Japanese and Indian nationality often use metacognitive strategies. Japanese language learners do not only keep track of their own language development, but they also make a plan for it (Wen, 1996, p. 41). Chen (2008) has observed the low usage frequency of the metacognitive strategies with Chinese language learners coming from different countries of Europe (p. 54). Wen (1996) study has also shown the low frequency of the usage of the metacognitive strategies (p. 38). The high frequency usage of the metacognitive strategies can be explained by the fact that language learners are very consciously looking for the method that is suitable for helping them in efficiently learning Chinese. It takes a longer time for Chinese language learners to realize which strategies can be applied in order to better acquire the language.

It is interesting that the frequent usage of (metacognitive, cognitive) strategies requiring the planning and organizing of language learning was observed among dyslexic children (Napravszky, Judiy \& Katalin, 2009, p. 69).

The fact that language learners use most of the strategies quite often can be interpreted in two ways. Literature refers to the experience acquired with the languages previously studied as the language learning experience, and the acquired knowledge help the language learner as positive transfers in learning a further language. "It is a fact without a doubt that one or several foreign languages already learned play an important role in the study of a foreign language started later on" (Budai, 2010, p. 12). In the study of the Chinese language the usage of the strategies applied with the languages already acquired do not help or help only to a lesser extent, so language learners are trying to overcome difficulties coming up in the initial phase of studying Chinese by using very many strategies very actively. That is why the role of strategies applied during the study of other languages is neglectable at the beginning of the learning of the Chinese language.

However, intensive strategy usage can mean a certain helplessness, which makes itself revealed in the eventually not suitable strategy use:

I was trying also at home to find out what the most effective way was, because I did not have any kind of tools, nobody ever told me how to learn. It is good to learn Chinese because I experimented with myself as for what it is I can set my mind on... (Kozjek-Gulyás, 2013, p. 91)

\section{Chinese Language Learning Strategies of University Student Language Learners}

With the help of the smallest space analysis of multidimensional scaling, I have established a model that describes the usage of the Chinese language learning strategies of language learners ${ }^{3}$ (Lengyel, 1999, p. 54).(as shown in Figure 2)

\footnotetext{
${ }^{3}$ MDS: Multi Dimensional Scaling. The position of the inputs is given by the geometric shape formed by the points in the space. This data analysis method can be applied excellently to the analysis of the hard to interpret, soft data of social sciences, psychology and sociology.
} 


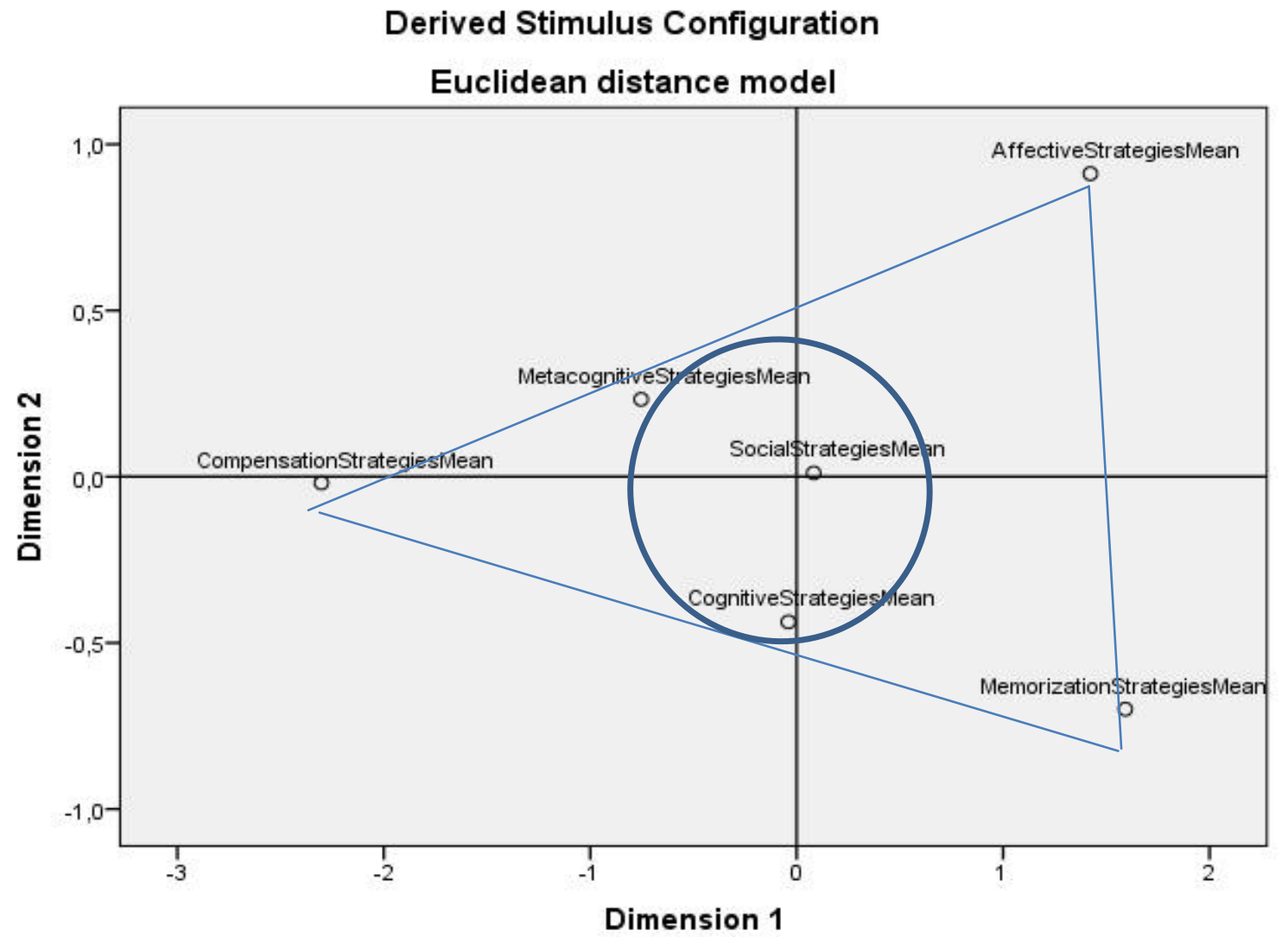

Figure 2. MDS: Multi Dimensional Scaling.

From the spatial arrangement of the six groups of the language learning strategies we can state that the Chinese language learning of language learners is determined by the frequent usage of three strategies, the social (K1_K5), the metacognitive (K_11K_16) and the cognitive (K27_K36) strategies. These primary strategies are surrounded by three secondary - the emotional (K6_K10), the compensation (K17_K21) and the memorization (K22_K26) strategies in the shape of a triangle. The opposition of the primary, central strategies to the secondary strategies means that these strategies are less dominant in Chinese language learning. Those language learners who use emotional strategies, use memorization and compensation strategies less. Those who use compensation strategies avoid the use of the memorization and emotional strategies - that is where the triangle comes from.

Out of the strategies playing a primary role, the use of the metacognitive strategies is the second most important in the learning of the Chinese language. The frequent use of the primary strategies of the Chinese language - the metacognitive, the cognitive and the social strategies - is more characteristic of women.

The cognitive strategies are least used by language learners learning Chinese for less than a year, and they are most used by those who have been learning the Chinese language for already four years.

One possible explanation for the less frequent usage of the cognitive strategies is that the mechanical, monotonous repetition of words makes the learning of a language boring. Another explanation is that the language learner is less aware of techniques that help the effective use of the cognitive strategies. The frequent use of the cognitive strategies is positively influenced by the outer motivation of the successfully passed language exam. 
Of the strategies playing a secondary role in the Chinese language learning of language learners, the use of the memorization strategies differentiates most the certain language learner groups possessing language knowledge from each other. With the increase of the level of the language knowledge the use of the memorization strategies becomes more frequent. The fact that the frequent usage of the memorization strategies is characteristic of beginner language learners is easily understandable, since in the initial phase of language learning the memorization of the characters and the pronunciation poses a certain challenge for the beginner Chinese language student. However, the frequent use of the memorization strategies is characteristic of not this language learner group, but of those language learners who have been learning Chinese for over four years.

The memorization strategies are preferred by the language learner group of good language knowledge level, as opposed to the average or not good language learner groups.

The background variable of the time spent having learned Chinese positively influences the use of the memorization and cognitive strategies.

The use of the compensation strategy can be considered as a constant strategy of language learners during the study of the Chinese language (also including the language learner group having a good language knowledge). With the progression of the time spent learning the Chinese language, the increasingly frequent use of the compensation strategies is equally characteristic of all language learner groups. The frequent application of the compensation and cognitive strategies changes depending on the background variable of the language learning time spent in the target language environment.

\section{Chinese Verbal Language Learning Strategies of Language Learners}

During the verbal acquisition of the Chinese language, language learners apply strategies related to the management and organization of language learning more often (average $=3.65$ ) than strategies connected to language usage itself (average $=3.29$ ).

Of the two subgroups of the strategies related to language usage, the frequency of the usage of the traditional strategies - form centered practice, the strategy of striving for accuracy, the strategy of the use of the mother tongue - received a higher value (average $=3.29)$ than the use of such non-traditional strategies (average $=3.06)$ as the compensation one, or the strategy usage of meaningful practice and the avoidance of the mother tongue.

In the use of the traditional verbal language learning strategies, the strategy of the use of the mother tongue received the highest frequency value (average $=4.09$ ). This was followed by the frequent usage of the strategy of striving for accuracy (average $=3.9$ ), the metacognitive strategies (average $=3.83$ ), the compensation strategies (averag $=3.75$ ) and the social strategies (average $=3.57$ ), and also by the sometimes used strategy of form centered practice (average $=3.47$ ). Of the usage of the non traditional verbal strategies, the strategy of the avoidance of the mother tongue (average $=3.45$ ), the meaningful practice (average $=2.83$ ) and the strategy of the strive for continuity (average $=2.65$ ) qualify as sometimes used strategies (as shown in Table 2).

According to the verbal strategy usage model of language learners (Figure 3), the use of the verbal strategies of the Chinese language learning takes the shape of a "sideways leaning pot" (or a U shaped horseshoe), on which the individual strategies are situated almost without intermission, as chain links. Language learners use almost all verbal language learning strategies constantly and intensively in order to enhance and improve the level of their Chinese language knowledge. 
Table 2

Sequence of strategies used in the learning of spoken Chinese

\begin{tabular}{llll}
\hline & Verbal strategy & Mean & Std. Deviation \\
\hline 1 & use of mother tongue & 4.09 & 0.90 \\
2 & strive for accuracy strategies & 3.90 & 1.12 \\
3 & metacognitive strategies & 3.83 & 0.77 \\
4 & compensation strategies & 3.75 & 0.73 \\
5 & social strategies & 3.57 & 0.95 \\
6 & formal strategies & 3.47 & 0.78 \\
7 & avoidance of mother tongue & 3.45 & 1.19 \\
8 & affective strategies & 3.27 & 0.89 \\
9 & meaningful practices & 2.83 & 0.83 \\
10 & fluency strategies & 2.65 & 1.11 \\
\hline
\end{tabular}

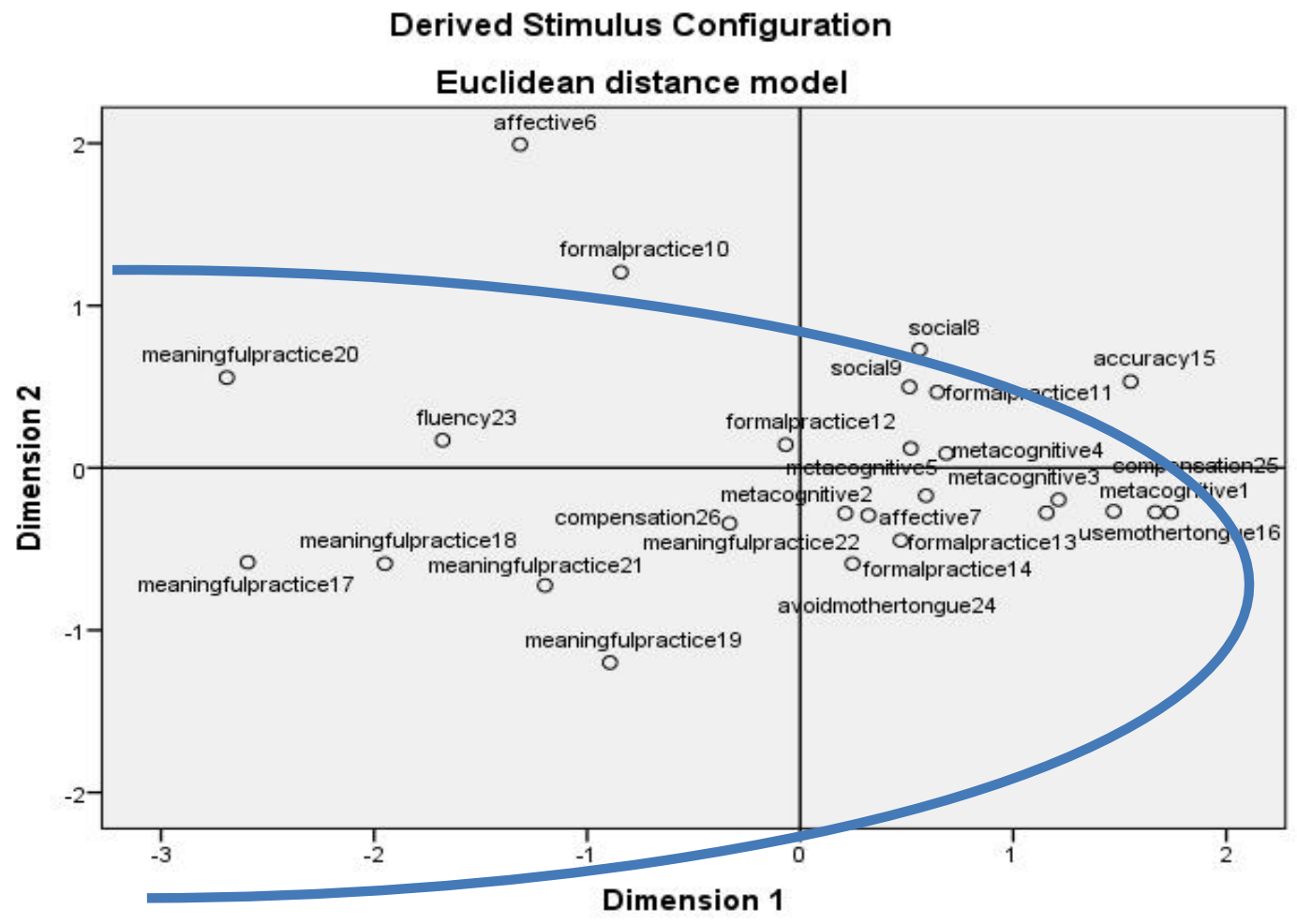

Figure 3. MDS (smallest space analysis) model of verbal strategies.

Four verbal strategies - the two strategies of meaningful practice, the strategy of the strive for continuity and the strategy of form centered practice are situated as individual points in the space, the use of these is not preferred by language learners during their Chinese language learning. The use of the strategy of the strive for continuity is the least characteristic of their Chinese language learning.

Chinese language learners intensively use the strategy of the use of the mother tongue in the acquisition of the verbal Chinese language. The use of the mother tongue is more frequently applied by the members of the language learner group that has a good language knowledge, than by those belonging to the language learner groups of average or not good language knowledge. The use of this traditional verbal strategy is not influenced by any background variable, which is something that definitely has to be built on during teaching the Chinese 
language. Only the manifest variable of the preparation for the language exam can influence language learners to give up the frequent use of the mother tongue, and in parallel start using the strategy of the avoidance of the mother tongue.

The background variable of the target language environment is the one that activizes the use of several verbal strategies, and also, it not only does not decrease the use of the verbal compensation strategies, but it intensifies their use. The communication experienced and practiced in the target language environment is able to overcome those deficiencies that situations learned in the classroom or in the mother tongue environment cannot surmount. The language learner is faced with the use of the strategies coming from the cultural deficiencies in the target language environment. While in the mother tongue environment the lack of the knowledge of culture means the biggest difficulty, the target language environment makes the use of the mother tongue more frequent with the realization of the cultural lack and the exploration of the linguistic and cultural differences.

The target language environment affects the use of such non traditional strategies as the strategy of meaningful practice, which plays a role in the processing of the linguistic and cultural inputs. Also, the target language environment influences most effectively the success and efficiency of the management, organization and language usage strategies of the verbal learning of the Chinese language. It further intensifies the frequent use of the verbal metacognitive strategies with the group of those possessing a good language knowledge.

The techniques aimed at and paying attention to the linguistic content and the accuracy of the forms are primarily used by language learners belonging to the group of those under 20 years of age, while members of the older language learner group (above 30) use these techniques less.

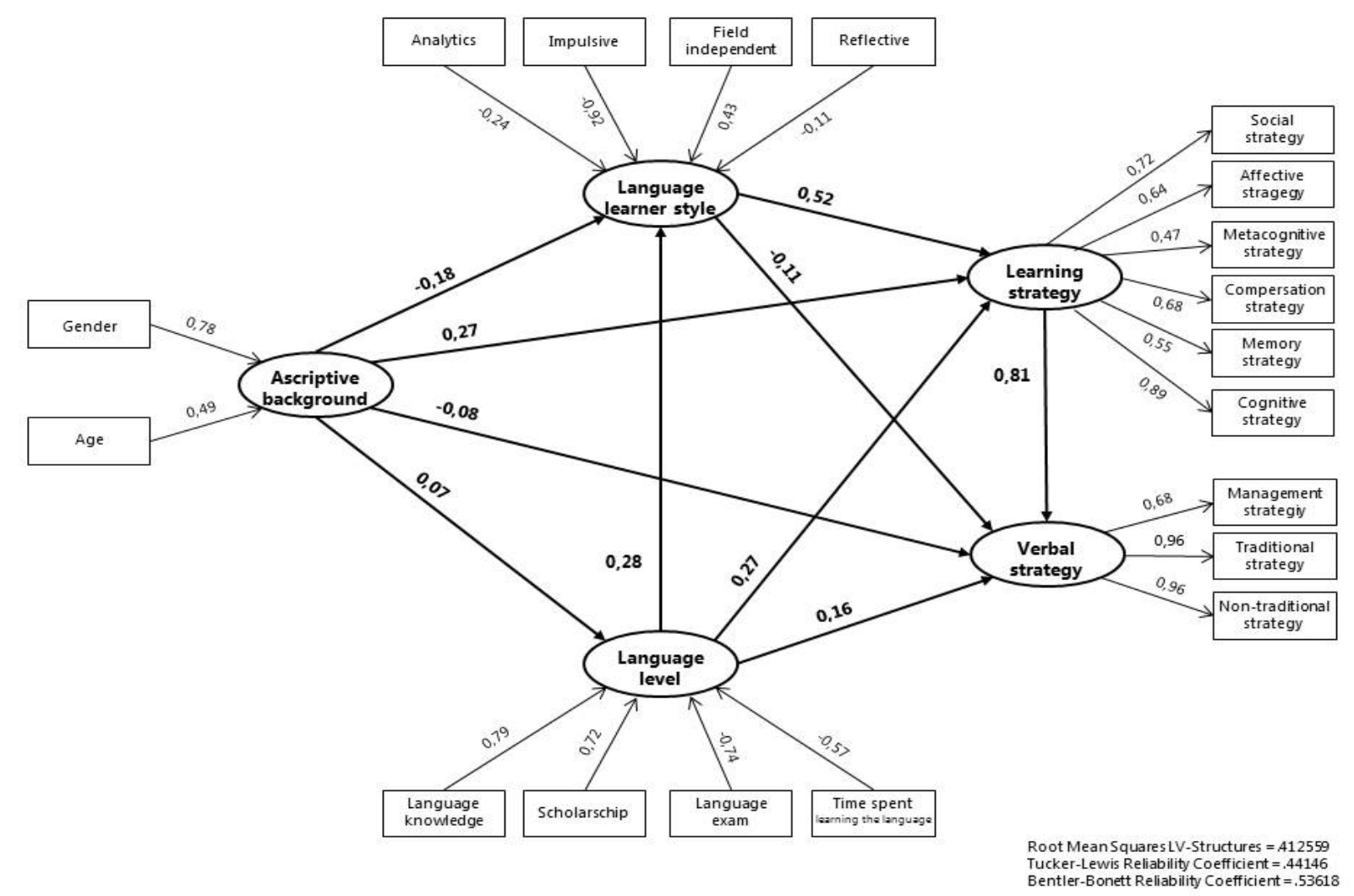

Figure 4. Latent Variables path analysis with Partial Least-Squares Estimation LVPLS model. 


\section{The Effect of the Individual Background Variables on Chinese Language Learning}

The autohr examined the effect of the background variables playing a role in the teaching of the Chinese language, the language learning and verbal language learning strategies, as well as that of the language learner styles on the successful acquisition of the Chinese language with the establishment of the LVPLS model (Figure 4), in which the author explored the connection system between the latent variables behind the manifest variable blocks.

Table 3

Path coefficient matrix (direct effect)

\begin{tabular}{|c|c|c|c|c|c|}
\hline Latent variables & Ascriptive background & Language level & Language learner style & Learning strategy & Verbal strategy \\
\hline Ascriptive background & - & & & & \\
\hline Language level & 0.07 & - & & & \\
\hline Language learner style & -0.18 & 0.28 & - & & \\
\hline Learning strategy & 0.27 & 0.27 & 0.52 & - & \\
\hline Verbal strategy & -0.08 & 0.16 & -0.11 & 0.81 & - \\
\hline
\end{tabular}

Table 4

Reduced Path coefficients (total effect $=$ direct effect + indirect effect)

\begin{tabular}{lcllll}
\hline Latent variables & \multicolumn{2}{l}{ Ascriptive background Language level } & Language learner style & Learning strategy & Verbal strategy \\
\hline Ascriptive background & - & & & & \\
Language level & 0.07 & - & & & \\
Language learner style & -0.20 & 0.28 & - & - & - \\
Learning strategy & 0.15 & 0.42 & 0.52 & 0.81 & - \\
Verbal strategy & 0.05 & 0.47 & 0.32 &
\end{tabular}

Table 5

Squared multiple correlations

\begin{tabular}{llllll}
\hline Latent variables & Ascriptive background & Language level & Language learner style & Learning strategy & Verbal strategy \\
\hline $\mathrm{R}^{2}$ & - & 0.01 & 0.11 & 0.44 & 0.68 \\
\hline
\end{tabular}

The model explains the two endogen variables, the learning strategy and the verbal strategy very well, it was able to reproduce $44 \%$ and $58 \%$ of the variance of the two latent dependent variables, which counts as a high value. The LVPLS model estimates the structural correlation system of the latent variables of the model with the method of the partial least squares. The exogen ascriptive background (which is defined by the gender with a large weight (0.78), and by the age with a smaller weight (0.49) has the greatest effect on the endogen variable of the learning strategy $(0.27)$ out of its path coefficients. This means that a unit of change in the ascriptive background influences the endogen variable of learning strategy (and through it further six different learning strategies) with (0.27) units (this counts as a high value with the latent path analysis). It also has a significant effect on the choice of the language learner style (-0.18). The positive and negative signs mean that out of the manifest variables behind the language learner style the impulsive style is positively influenced, while the field independent style is negatively influenced. The ascriptive background is unable to have even a third of the effect on the latent variables of the other two blocks of the LVPLS model, however, these influences are still significant. It is interesting that the whole effect of the exogen ascriptive latent variable not only did not increase, but it 
decreased, except for the fact that the previously negative effect on the verbal strategy became positive, which is an important sign of the background being able to influence the choice of the verbal strategy via the filters of the language learner style and the language level.

The language level latent block significantly influences the language learner style and the learning strategy (the two coefficients being 0.28 and 0.27 ), and to a lesser, but still significant extent it also influences the verbal strategy (0.16). The whole influence of the language level considerably increases with the special effect it has on the two endogen latent variables (its effect on the learning strategy is 0.42 , and on the verbal strategy it is 0.47 ) through the language learner style block.

The path coefficient of the language learner style latent variable related to the learning strategy is very high, (0.52), this determines most of all the kind of language learning strategy one chooses during the learning of the Chinese language. Out of the four manifest variables of the language learner style (analytic, impulsive, field independent, reflective) the field independent style has a positive weight (0.43), while in the cases of the other three styles the weights are negative (the analytic (-0.24), the impulsive (-0.92) and the reflective styles (-0.11)). The latent variable of style expresses the impulsive vs. field independent bipolarity. The latent variable of style expresses the field independent learning style in the positive direction, while in the negative direction it expresses the impulsive learning style. The impulsive style significantly influences the choice of the verbal strategy (-0.11).

The whole influence of the language learner style has on the verbal strategy almost trebles together with the specific influence it has through the learning strategy (0.32).

The latent variable of the language learning strategies is best defined by the use of the cognitive (0.89) and the social strategies $(0.72)$. The better student one is, the more social and cognitive language learning strategies they use in order to be successful in the learning of the Chinese language. Out of the factor weights of all the strategies, the factor weight of the metacognitive strategy (0.47) received the lowest value, although it can be said to still be a high value. The factor weight of the memorization strategy shows a little higher value $(0.55)$ than the usage of the metacognitive strategies.

The learning strategy latent variable influences the choice of the verbal strategy with a quite high weight (0.81) - almost linearly, which signifies that the choice of the language learning strategy goes closely together with the choice of the verbal strategy.

\section{The Role of the Language Learner Styles in Chinese Language Learning}

The choice and use of the language learning strategies is strongly influenced by the language learning style. Instead of thinking of it as a factor that is liable to stereotypes and classifications, the learner style is worth conceptualizing as a continuum, or the repertoire of the language learner, in which the styles extending from one pole to the other offer possibilities for the language learner to choose from the usage of the styles when solving a given task.

The individual language learner types prefer different strategies during their language learning according to the style they are learning in, therefore the usages of the Chinese language learning and verbal strategies can be distinctly differentiated.

In the spatial demonstration of the language learner styles of the Chinese language, the smallest space analysis model of multidimensional scaling differentiates four kinds of language learner style dimensions. 
The space of the language learner styles of the Chinese language is defined by two bipolar dimensions. The two hemispheres of the space are divided by two latent dimensions. The author named one dimension ACTIVE, and the other REACTIVE latent dimension. On one pole of the ACTIVE latent dimension are situated the deductive-field dependent-meticulous-sharpening and closed language learner types, so the author named the right side pole of this dimension deductive-field dependent-meticulous-sharpening and closed (DAMÉZ, based on the initials of the characteristics in the Hungarian original) style indicator. The left side of the ACTIVE latent dimension, which is also the lower part of the left hemisphere of the two dimensional space, received the name open-inductive-leveler-global-field independent (NYILGM) style indicator, based on the style indicators that can be found in that part of the space. In the lower quarter of the right hand hemisphere the elements of the second style indicator are metaphorical-impulsive-synthetising-extrovert-random, so based on this the author named it (MISZER) style indicator. In the upper quarter of the left hemisphere there is the third style indicator, which is called the literal-introvert-concrete-analytic-reflective (LIKAR) language learner style indicator. This is the left hand side style pair of the REACTIVE latent dimension (as shown in Figure 5).

\section{Derived Stimulus Configuration}

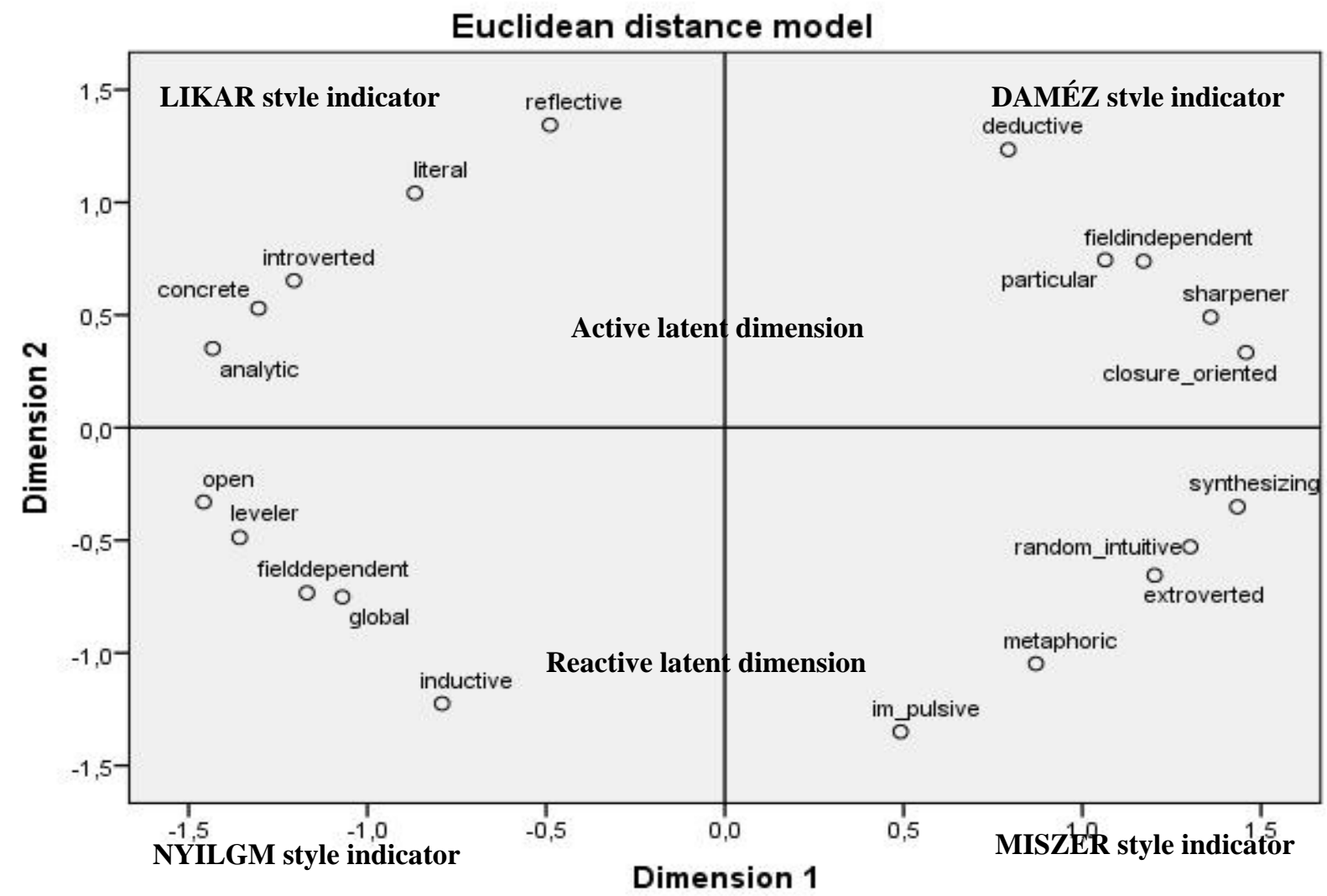

Figure 5. Language learner styles.

In the reactive latent dimension two style opposition pairs determining the Chinese language learning of language learners can be found: the impulsive and the reflective language learner styles. Impulsivity means quick responses in language learning situations, while its style opposition pair, reflectivity means the gathering and analysis of information before giving an answer. 
The impulsive and reflective language learner styles can be conceived as opposition pairs to each other in the use and choice of the strategies of Chinese language larning. In the successful acquisition of the Chinese language the impulsive language learner type can be said to be effective, since this style is characteristic of the group of good language learners, and it is not typical of language learners of average or bad language learning performance. Impulsivity requires greater risk taking from the part of the language learners, so it is an effective language learning style in the learning of Chinese. Language learners preferring the impulsive language learner style are characterized by the frequent use of the social, emotional and memorization strategies, while in verbal communication they generally avoid the emotional and compensation verbal strategies. The fact that impulsive language learners are typically quick responders does not exclude the use of the strategy of striving for accuracy. In the use of the cognitive strategies they can be characterized by inductive learning-language learning that progresses form specific examples to general rules.

The third language learner style indicator, the analytic is also situated in this latent dimension. The processing of information is performed with the help of logical analysis, basically by focusing on grammatical forms.

In the active latent dimension the field independent language learner style indicator of language learners can be found (NYILGM). Language learners preferring the field independent way of thinking can separate the stimuli from the situation, the environment, while with field dependent language learners the perception of the objects is strongly influenced by the environment.

Out of the language learner styles, the strongest correlation with the effectiveness of the language learning is shown by language learners having a field independent thinking style. The field independent student is able to analyze the problem by analytically analyzing it, taking it into parts, drawing conclusions, which shows a close correlation with performance as well (Bárdos, 2000, p. 239). On the basis of the results of the research I was not able to confirm the statement that students preferring the field independent thinking style achieve better results in learning Chinese, since language learners belonging to this category belonged to the groups of average or that of the not good language learners. Field independence can also mean that this is the language learning style the users of which do not choose strategies. On the other hand, the field dependent language learners preferred the use of three strategies: the metacognitive, the memorization and the cognitive.

On the basis of the sensory organs used in the process of learning three types can be differentiated: visual, auditive and sensory-motor type language learner (Oxford, 2003, p. 3). In the case of the learning of Chinese, out of the three types it is students preferring the auditive style who achieve good results in the learning of the Chinese language. The use of the visual technic is less characteristic of good language learners, although they do prefer the use of the metacognitive, memorization, and cognitive strategies, as well as the verbal metacognitive strategy and the strategy of form centered practices.

Among students the preference of the auditive style can be observed (Kontráné, 2004, p. 97). In the cases of English and German surveys have been performed to describe the sensory organ preferences of dyslexic and non-dyslexic children. In the case of German, the sequence of the preferences was also auditive, visual and haptic in both the general and the dyslexic language groups (Napravszky, Judit \& Katalin, 2009, p. 69). In the case of English, both the average and the dyslexic students preferred the auditive style. The results show that students preferring the auditive style are successful in the course of their Chinese language learning. 


\section{Summary}

In my research I undertook the survey of the language learning strategies of the language learners and the characteristics of their language learning styles. I was trying to find an answer to the question of how the characteristics of the Chinese language influence the usage of the language learning strategies and styles.

Of the results of the survey we can learn the following lessons. The linking together of the cognitive and memorization strategies and their joint usage results in successful Chinese language learning. They can help in the learning of the structure of the characters in a logical way, supporting and supplementing each other. In the learning of the Chinese language one year is a sufficient time for the language learner to realize the "coding" of the characters of the Chinese language, and for them to prefer the cognitive strategies to the memorization strategies.

The language learner style has the strongest structural influence on the acquisition of the Chinese language. Therefore, it would be worthwhile to make recommendations for the strategy choice that is the most possibly congruent with the personal traits

The survey summarizes the most often used Chinese language learning strategies and verbal language learning strategies of Hungarian language learners one by one.

With the help of the method of multidimensional scaling, the survey got to the result that the preference of the general language learning strategies is characterized by a strong opposition. In the case of the choice and use of three strategies, the social, the metacognitive and the cognitive strategies, language learners prefer a combined choice or non-choice. While in the use of the emotional, compensation and memorization strategies a strong opposition emerges. Those using memorization strategies less prefer the emotional and and the compensation strategies. This is true vice versa as well, those using emotional strategies, use memorization and compensation strategies less often.

While the relation of the general language learning strategies was characterized by a certain opposition, in the use of the verbal strategies a strict continuity could be detected. Hungarian language learners consider the use of almost all verbal strategies with few exceptions to be successful in their communication.

The results of the LVPLS model revealed all those connections that structurally exist among the three exogen background latent variables (language level, language learner style and the ascriptive background) and the two endogen latent variables (the language learning strategies and the verbal strategies). All of these latens variables measured with several manifest variables.

Of the second exogen background variables, the language learning style showed the biggest effect on strategy use, this variable influences the successfulness of the learning of Chinese most strongly.

Taking into account the different linguistic characteristics of the Chinese language, its learning requires different approaches from the learner. The process of acquiring the Chinese language is in many respects similar to that of other languages, however, the strategy usage shows differences from the cases pf the English and German languages.

The results of the research of the language learning strategies and styles can also provide help in including task types in language books that take into account the effective strategies and styles used during the learning of the Chinese language. 
A research extended to include the strategy use of young language learners may refine the more detailed knowledge of the influence of the ascriptive background (age and sex).

\section{Reference}

Bárdos, J. (2000). Az idegen nyelvek tanításának elméleti alapjai és gyakorlata (The theoretical bases and practice of teaching foreign languages). Budapest: Nemzeti Tankönyvkiadó.

Budai, L. (2010). Az anyanyelv változó szerepe az idegennyelv-oktatásban (the changing role of the mother tongue in foreign language teaching). Budapest: Nemzeti Tankönyvkiadó.

Benő, C. (2001). A nyelvtanulást és a nyelvtudást befolyásoló tényezők. Iskolakultúra, 8.

Chen, X. F. (2008). 留学生汉语学习策略研究 (Survey of the Chinese language learning strategies of foreign language learners). Master's thesis, Xiamen University.

Ehrman M. E., \& Oxford, R. L. (1989). Effects of sex differences, career choice and psychological type on adult language learning strategies. Modern Language Journal, 73(1), 1-13.

Ehrman, M. E., \& Oxford, R. L. (1990). Cognition plus: correlates of language learning success. Modern Language Journa, 79.

Füstös, L. (2009). A sokváltozós adatelemzés módszerei (The Methods of Multivariable Data Analysis). (Módszertani Füzetek).Budapest: MTA Szociológiai Kutatóintézete, Társadalomtudományi Elemzések Akadémiai Műhelye (TEAM).

Jiang, X. (2000). 汉语作为第二语言学习策略初探 (A Primary study on learning strategies of Chinese as a second language). Language Teaching and Linguistic Studies, 1.

Kontráné, H. (2004). Gimnazista nyelvtanulók tanulási stratégiái (Learning Strategies of Grammar School Language Learners). In Kontráné Hegybíró (Ed.), Kormos Judit (szerk.): A nyelvtanuló. Sikerek, módszerek, stratégiák (pp. 83-107). Budapest: Okker Kiadó.

Kozjek-Gulyás, A. (2013). A nyelvtanulási stratégiák szerepe a kínai nyelv tanulásában (The Role of the Language Learning Strategies in the Learning of the Chinese Language). Thesis, Eotvos Lorand University .

Lengyel, I. (1999). Mérni a mérhetetlent? A megyei jogú városok vizsgálata többdimenziós skálázással (To measure the immeasurable? Survey of the county centre cities with multidimensional scaling). Tér és Társadalom, 13(1-2), 53-73.

Lenneberg, E. (1967). Biological foundations of language. New York: Willey.

Katalin, M. (2004). Learner strategies of Hungarian secondary grammar school students. Budapest: Akadémiai Kiadó.

Napravszky, N., Judit, T., \& Katalin, M (2009). Diszlexiás és nem diszlexiás általános iskolai tanulók nyelvtanulási stílusainak és stratégiáinak összehasonlító vizsgálata (Comparative analysis of the language learning styles and strategies of dyslexic and non-dyslexic elementary school students). Új Pedagógiai Szemle, 1, 50-71.

Nyikos, M. (1990). Sex-related differences in adult language learning: Socialization and memory factors. Modern Language Journal, 74(3).

Nyikos, M. (1987). The effects of color and imagery as mnemonic strategies on learning and retention of lexical items in German. Thesis, Purdue University.

O’Malley, J. M., \& Chamot, A. U. (1990). Learner strategies in second language acquisition. Cambridge: Cambridge University Press.

Oxford, R. L., Nyikos, M., \& Ehrmann, M. E. (1988). Vive la difference? Reflections on sex differences in use of language learning strategies. Foreign Language Annals, 21(4), 321-329.

Oxford, R. L., \& Nyikos, M. (1989). Variables affecting choice of language learning strategies by university students. Modern University Journal, 73(3), 291-300.

Oxford, R. L. (1990). Language learning strategies: What every teacher should know. Englewood Cliffs, NJ: Newbury House.

Oxford, R. L. (2003). Language Learning Styles and Strategies: An Overview. Learning Styles \& Strategies (pp. 1-25). Oxford: GALA.

Oxford, R. L, Lavine, R. Z., Felkins, G., Holloway, M. E., \& Saleh, A. (1996). Telling their stories: Language students use diaries and recollective studies. In Oxford, R. L. (Ed.). Language learning strategies around the world: Cross-cultural perspectives. Manoa: University of Hawai'i Press.

Oyama, S. (1976). A sensitive period in the acquisition of a non-native phonological system. Journal of Psycholinguistic Research, $5,261-285$.

Rubin, J. (1975). What “the good language learner”can teach us. TESOL Quarterly, 9(1), 41-51. 


\section{CHINESE LANGUAGE LEARNING STRATEGIES CHARACTERISTIC OF LANGUAGE LEARNERS}

Tar, I. (2007). Az idegennyelv-tanulási stratégiák választásának összefüggései nyelvtanulási tapasztalattal és szorongással (The correlations of the choice of the foreign language learning strategies with the language learning experience and distres). Thesis, Debreceni Egyetem.

Wen, Q. (1995). 英语成功者与不成功者在方法上的差异 (Differences between the language learning methods of successful and unsuccessful English language learners). Foreign Language Teaching and Research, 3, 61-66.

Wen, Q. (1996). 传统和非传统学习方法与英语成绩的关系 (Connection between the traditional and non-traditional learning methods and the successfulness of learning the English Language). Modern Foreign Languages, 1, 37-43.

$\mathrm{Wu}$, Y. (2007). 不同环境下的外国人汉语学习策略研究 (Analysis of the Chinese language learning strategies of foreign students studying in different linguistic environments). Thesis, Shanghai Normal University.

$\mathrm{Wu}$, Y. (2008). 意大利学生汉语口语学习策略使用的个案研究 (Analysis of the verbal Chinese language learning strategies of Italian students). Chinese Teaching In The World, 4, 88-100.

Xu, Z. (2006). 不同认知风格的汉语学习者在学习策略运用上的差异研究 (A study on different use of learning strategies for Chinese learners with different cognitive styles). CN: Foreign Teaching and Research Press.

Young, D. J., \& Oxford, R. L. (1997). A gender-related analysis of strategies used to process written input in the native language and a foreign language. Applied Language Learning, 8(1), 26-43. 